\title{
Assessment of Heavy Metals in Indoor Settled Harmattan Dust from the University of Agriculture Makurdi, Nigeria
}

\author{
Ishaq S. Eneji ${ }^{*}$, Itodo U. Adams ${ }^{1}$, Kadili A. Julius ${ }^{2}$ \\ ${ }^{1}$ Department of Chemistry, Federal University of Agriculture, Makurdi, Nigeria \\ ${ }^{2}$ Department of Chemistry, Kogi State College of Education (Technical), Kabba, Nigeria \\ Email: *ishaqeneji@gmail.com
}

Received 7 September 2015; accepted 11 December 2015; published 14 December 2015

Copyright (C) 2015 by authors and Scientific Research Publishing Inc.

This work is licensed under the Creative Commons Attribution International License (CC BY). http://creativecommons.org/licenses/by/4.0/

(c) (i) Open Access

\begin{abstract}
Indoor settled harmattan dusts at seven sampling stations from the University of Agriculture Makurdi were collected between November, 2014 to March, 2015 (five months) using the wipe sampling methodology. Gravimetric measurement of the dust samples from all the sample locations revealed that dust loading within the institution during the period of assessment ranges from $4.475-6.533 \mathrm{~g} / \mathrm{m}^{2}$. Masses of indoor settled dust were expectedly higher along high traffic, untarred roads and construction sites as well as in older buildings than others during the period of this study. AAS analysis of the dust samples shows that heavy metal concentrations $(\mathrm{mg} / \mathrm{kg}$ dry weight) throughout the sampling stations during the period of investigation range from 0.2372 0.7152 for $\mathrm{Cu}, 293.6$ - 884.9 for $\mathrm{Fe}, 4.265$ - 68.55 for Mn and 4.239 - 42.53 for $\mathrm{Zn}$. The concentrations of all the metals investigated were found to be lower when compared with related values in literature and were within acceptable limits during the period of this study. Pearson correlation matrix also shows positive correlation between the possible metal pairs at $95 \%$ level of confidence, indicating a similar source which may be from anthropogenic activities within and outside the area.
\end{abstract}

\section{Keywords}

Heavy Metals, Settled Dust, Harmattan, University of Agriculture Makurdi, Correlation Matrix

\section{Introduction}

The Harmattan is a cold-dry and dusty trade wind, blowing over the West African sub region. This northeasterly *Corresponding author.

How to cite this paper: Eneji, I.S., Adams, I.U. and Julius, K.A. (2015) Assessment of Heavy Metals in Indoor Settled Harmattan Dust from the University of Agriculture Makurdi, Nigeria. Open Journal of Air Pollution, 4, 198-207.

http://dx.doi.org/10.4236/ojap.2015.44017 
wind blows from the Sahara Desert into the Gulf of Guinea between the end of November and the Middle of March (winter) [1]. During this season, temperatures can easily be as low as $9^{\circ} \mathrm{C}\left(48^{\circ} \mathrm{F}\right)$. However, sometimes in the afternoon the temperature can soar to as high as $30^{\circ} \mathrm{C}\left(86^{\circ} \mathrm{F}\right)$, while the relative humidity drops under $10 \%$ [1]. The Harmattan season differs from winter because it is characterized by cold-dry, dust-laden wind, and also wide fluctuations in the ambient temperatures of the day and night. On its passage over the Sahara, it picks up fine dust and sand particles (between 0.5 and 10 micrometres).

The air is particularly dry and desiccating when the Harmattan blows over the region. Dust according to Adekola and Dosumu [2] can be defined as matter or particulate in the form of fine powder, lying on the ground or on the surface of objects or blown about by the wind. Dust emanate from complex interplay between wind and particulate matter suspended in the atmosphere. Anthropogenic dust comes from particulate matter which has been disturbed by wind or human activities such as earth moving vehicles, traffic on paved and unpaved surface [3]. The composition of dust is complex and contains organic and inorganic as well as microbial entities [4]. Ediagbonya et al., [5] noted that the greatest air pollution in Nigeria environment is atmospheric dust. They can be of natural or anthropogenic origin and poses potential threats to humans and animals. According to Rashad and Shalaby [6], agriculture (irrigation with polluted waters, sewage sludge and fertilizer, especially phosphates, contaminated manure and pesticide and pesticide containing heavy metals), waste incineration, combustion of fossil fuels and road traffic, long-range transport of atmospheric pollutants adds to the metals in the natural environment.

Many studies on settled dust have focused on elemental concentrations and source identification [7]-[9]. These and other studies suggested that humans are exposed to metal pollutants through many pathways such as inhalation of dust or unintentional hand to mouth contact since these metals can be easily embedded in dust from far distance especially from industries [10]. According to Gbadebo and Bankole [11], the health effects of these toxic metals in dust when inhaled can inflame, sensitize and even scar the lungs and tissue because these metals are ubiquitous in the environment.

Considerable attention has been paid to the study of metal pollution in city air, residential house dusts, roadside dusts and soils. However, there is little concern of the presence of these metallic pollutants in indoor dust in public offices. Since there are limited data on dust contamination in offices, this study is important and timely. The aim of this work was to determine the concentrations of heavy metals indoors by examining dust from selected offices of the Federal University of Agriculture Makurdi, Nigeria. The information obtained will form the basis that can be used for planning and management strategies to achieve a better environmental quality in the University, as well as serve as baseline for further studies in the area.

\section{Materials and Method}

\subsection{Study Area}

Makurdi town is the headquarters of Makurdi Local Government Area and capital of Benue State, generally known as the "Food Basket" of Nigeria. The town is located between latitude $7^{\circ} 38^{\prime} \mathrm{N}-7^{\circ} 50^{\prime} \mathrm{N}$, and longitude $8^{\circ} 24^{\prime} \mathrm{E}$ and $8^{\circ} 38^{\prime} \mathrm{E}$ with a total area of $200 \mathrm{~km}^{2}$. It is situated in the Benue valley in the North Central region of Nigeria with population of 500,791 people. It is traversed by the second largest river in the country, the River Benue (Figure 1).

University of Agriculture Makurdi (UAM) is located in Makurdi and it occupies an arable land area of 8048 hectares. The University is made up of nine (9) Colleges and thirty nine (39) Departments spread throughout its North Core and South core campuses. Several agricultural activities take place within the institution with the application of modern technologies such as the use of tractors, fertilizers, herbicides and pesticides of different sorts. This as well as the heavy traffic witnessed on daily basis contributes to the presence of substantial amount of heavy metals within the indoor environment of the institution.

\subsection{Sampling}

Reagents of analytical grades procured from Sigma Aldrich, USA were utilized in this study without further treatments.

The wipe sampling methodology was employed in this study for the collection of indoor settled dust. Dust wipe samples were collected according to the American Society for Testing and Material, ASTM E1728 protocol [12] as adopted by McDonald et al., [13] and National Institute for Occupational Safety, NIOSH 9100 method 


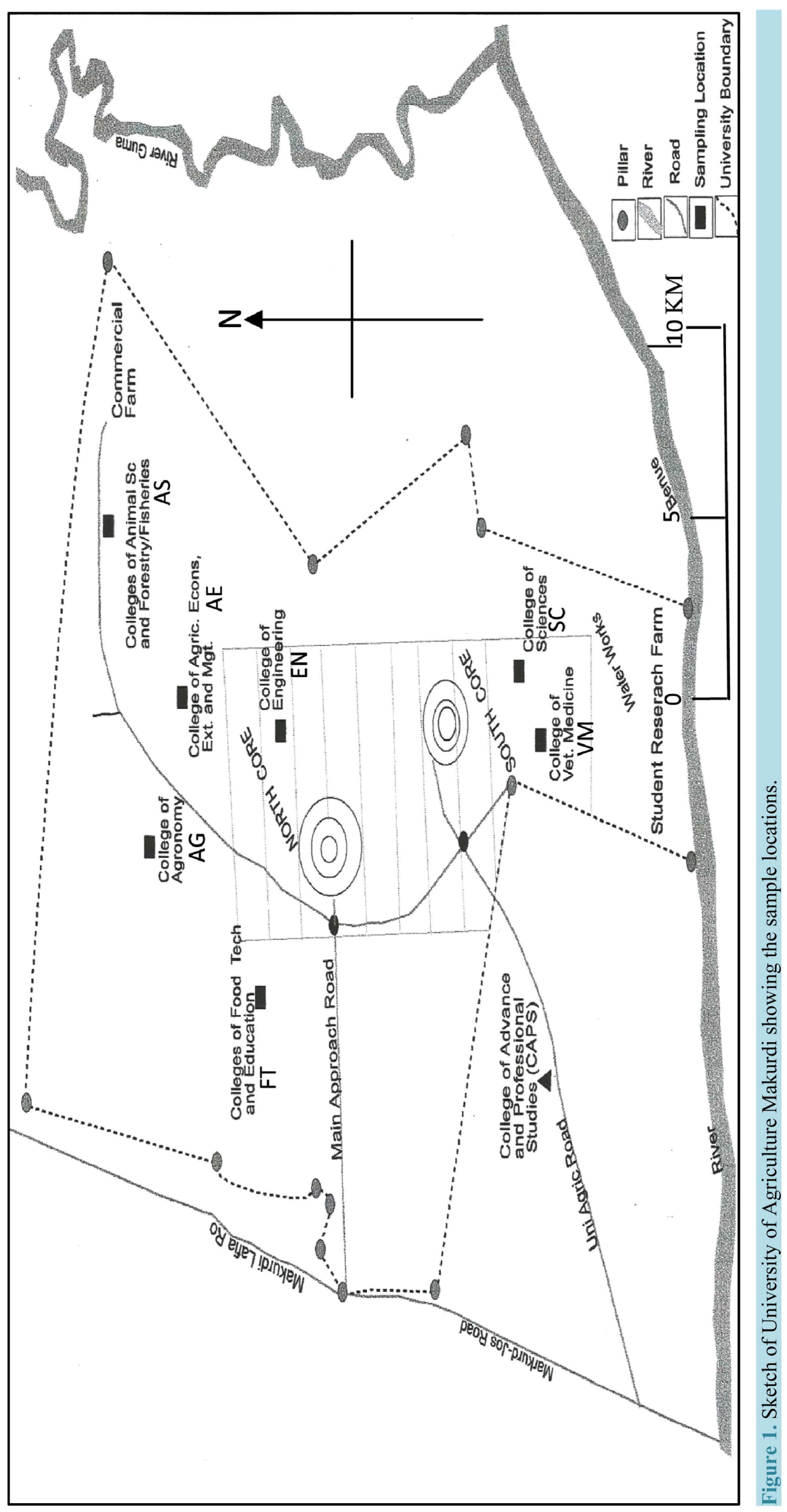


[14] as reported by Brook Haven National Laboratory [15]. This prescribes a vertical and horizontal overlapping S-shape movement, applying even pressure to the wipe surface to ensure that every space in the demarcated area is wiped twice. In this study, a $900 \mathrm{~cm}^{2}$ plastic template (for desks) and a $100 \mathrm{~cm}^{2}$ template (for ceiling fan blade) were used to constrain the wipe sampling area as prescribed by the ASTM E1728 protocol [12] and NIOSH 9100 method [14]. The templates were cleaned between each office and a new template was used for each College building. This is according to the guidelines provided by McDonald et al. [13]. After sampling the area, the wipe material were folded with the contaminated side on the interior and placed into a pre-labeled sealable bag (Ziploc). The number of wipe material used per sampling depended on the visual observation of surface load.

Ashless filter paper (Whatman no 42) was used as the wipe material in this study. The researcher selected filter paper out of many brands of wipes available, because filter papers completely digest in acid and they contain very low background concentrations of the metals under study. Filter papers were weighed before and after sampling using electronic analytical balance. This was to determine the level of dust loading in different sampling sites. Before weighing, the samples were equilibrated in desiccators at $20^{\circ} \mathrm{C}-30^{\circ} \mathrm{C}$ in a humidity controlled room for $24 \mathrm{~h}$ [16]. This was to prevent any possible error in the mass of samples as a result of available moisture.

In this study, sampling of indoor settled dust was conducted between the months of November, 2014 and March, 2015 (five months) representing the dry harmattan season when there is high prevalence of dust in the study area. Outdoor settled dust samples were also collected from the vicinities of sampled College buildings during the same period to serve as control. Twenty one offices (three from each of the seven buildings housing the nine Colleges of the University) were selected at random for this study. A total of 210 wipe samples of indoor settled dust were collected from office desks $\left(900 \mathrm{~cm}^{2}\right)$ and ceiling fan blades $\left(100 \mathrm{~cm}^{2}\right.$ each) not previously rusted. While a total of 30 samples of outdoor settled dust was collected from three locations A, B and C within the vicinities of the sampled College buildings during the same period to serve as control. In each College building sampled, one field blank tissue paper was exposed to all handling procedures used for the samples with the exception that no surface was wiped [12] [13]. This quality control measure was to reduce gravimetric bias and also to account for any cross-contamination and possible background concentration of the filter papers. Immediately following completion of sampling, all wipe samples were transported back to the laboratory for digestion and analysis. The various sample locations and their respective office codes are listed in Table 1.

Table 1. Sampling site characteristics including geographic coordinates (decimal degrees), elevation, site classification and sampling period.

\begin{tabular}{|c|c|c|c|c|}
\hline College Building & Sample Code & Coordinate & $\begin{array}{l}\text { Control } \\
\text { Code }\end{array}$ & Coordinate \\
\hline Sciences & $\begin{array}{l}\text { SC1, SC2, } \\
\text { SC3 }\end{array}$ & $\begin{array}{c}\text { latitude } 7^{\circ} 45^{\prime} \mathrm{N} \text {, longitude } \\
8^{\circ} 37^{\prime} \mathrm{E} \text { and Altitude } \\
143.0 \text { meters }\end{array}$ & A & $\begin{array}{c}\text { latitude } 7^{\circ} 45^{\prime} \mathrm{N} \text {, longitude } 8^{\circ} 37^{\prime} \mathrm{E} \\
\text { and Altitude } 129.0 \text { meters }\end{array}$ \\
\hline Veterinary Medicine & $\begin{array}{l}\text { VM1, VM2, } \\
\text { VM3 }\end{array}$ & $\begin{array}{c}\text { latitude } 7^{\circ} 45^{\prime} \mathrm{N} \text {, longitude } \\
8^{\circ} 37^{\prime} \mathrm{E} \text { and Altitude } \\
125.0 \text { meters }\end{array}$ & A & $\begin{array}{c}\text { latitude } 7^{\circ} 45^{\prime} \mathrm{N} \text {, longitude } 8^{\circ} 37^{\prime} \mathrm{E} \\
\text { and Altitude } 129.0 \text { meters }\end{array}$ \\
\hline Food Technology & $\begin{array}{l}\text { FT1, FT2, } \\
\text { FT3, }\end{array}$ & $\begin{array}{c}\text { latitude } 7^{\circ} 47^{\prime} \mathrm{N} \text {, longitude } \\
8^{\circ} 37^{\prime} \mathrm{E} \text { and Altitude } \\
122.0 \text { meters }\end{array}$ & B & $\begin{array}{c}\text { latitude } 7^{\circ} 47^{\prime} \mathrm{N} \text {, longitude } 8^{\circ} 37^{\prime} \mathrm{E} \\
\text { and Altitude } 119.0 \text { meters }\end{array}$ \\
\hline Engineering & $\begin{array}{l}\text { EN1, EN2, } \\
\text { EN3 }\end{array}$ & $\begin{array}{c}\text { latitude } 7^{\circ} 47^{\prime} \mathrm{N} \text {, longitude } \\
8^{\circ} 37^{\prime} \mathrm{E} \text { and Altitude } \\
134.0 \text { meters }\end{array}$ & B & $\begin{array}{c}\text { latitude } 7^{\circ} 47^{\prime} \mathrm{N} \text {, longitude } 8^{\circ} 37^{\prime} \mathrm{E} \\
\text { and Altitude } 119.0 \text { meters }\end{array}$ \\
\hline Agronomy & $\begin{array}{l}\text { AG1, AG2, } \\
\text { AG3 }\end{array}$ & $\begin{array}{c}\text { latitude } 7^{\circ} 47^{\prime} \mathrm{N} \text {, longitude } \\
8^{\circ} 36^{\prime} \mathrm{E} \text { and Altitude } \\
116.0 \text { meters }\end{array}$ & $\mathrm{B}$ & $\begin{array}{c}\text { latitude } 7^{\circ} 47^{\prime} \mathrm{N} \text {, longitude } 8^{\circ} 37^{\prime} \mathrm{E} \\
\text { and Altitude } 119.0 \text { meters }\end{array}$ \\
\hline Agric Econ \& Extension & $\begin{array}{l}\text { AE1, AE2, } \\
\text { AE3 }\end{array}$ & $\begin{array}{c}\text { latitude } 7^{\circ} 47^{\prime} \mathrm{N} \text {, longitude } \\
8^{\circ} 37^{\prime} \mathrm{E} \text { and Altitude } \\
1126.0 \text { meters }\end{array}$ & B & $\begin{array}{c}\text { latitude } 7^{\circ} 47 ' \mathrm{~N} \text {, longitude } 8^{\circ} 37^{\prime} \mathrm{E} \\
\text { and Altitude } 119.0 \text { meters }\end{array}$ \\
\hline Animal Science & $\begin{array}{l}\text { AS1, AS2, } \\
\text { AS3 }\end{array}$ & $\begin{array}{c}\text { latitude } 7^{\circ} 48^{\prime} \mathrm{N} \text {, longitude } \\
8^{\circ} 37^{\prime} \mathrm{E} \text { and Altitude } \\
137.0 \text { meters }\end{array}$ & $\mathrm{C}$ & $\begin{array}{c}\text { latitude } 7^{\circ} 48^{\prime} \mathrm{N} \text {, longitude } 8^{\circ} 37^{\prime} \mathrm{E} \\
\text { and Altitude } 128.0 \text { meters }\end{array}$ \\
\hline
\end{tabular}




\subsection{Gravimetric Measurement}

The surface concentration (loading) of dust loading in each office was found by subtracting the initial mass of filter paper (before sampling) from the final mass of filter paper (after sampling) using electronic analytical balance. Dust loading for each sample location was obtained using the following mathematical expression:

$$
D_{L}\left(g / m^{2}\right)=\frac{\left(M_{2}-M_{1}\right)}{A}
$$

where $D_{L}=$ Dust Loading $\left(\mathrm{g} / \mathrm{m}^{2}\right), M_{1}$ and $M_{2}$ are the initial and final masses (grams) of filter paper respectively and A represents the area $\left(\mathrm{m}^{2}\right)$ of surface wiped.

Dust wipe filter papers from each container were digested in concentrated analytical grade $\mathrm{HNO}_{3}$ on hot plate. After digestion, the contents in the beaker, upon cooling was then transferred quantitatively into a $50 \mathrm{~mL}$ volumetric flask and brought to volume with de-ionized water, filtered through ashless filter paper (Whatman no 42) and stored in polypropylene bottles prior to heavy metals analysis. $0.5 \mathrm{~g}$ of dust samples from each of the control sites as well as the blank samples were also digested following similar procedure. The Digests were then examined for the concentrations of $\mathrm{Cu}, \mathrm{Fe}, \mathrm{Mn}$ and $\mathrm{Zn}$ using Atomic Absorption Spectrophotometer (Shimadzu AA-6300).

\section{Results and Discussion}

\subsection{Dust Loading}

The experimental data collected in this research work are presented as tables as mean along with their standard deviations and bar charts. Table 2 shows indoor settled dust loading $\left(\mathrm{g} / \mathrm{m}^{2}\right)$ for all the sample locations during the period of assessment. Within the sampling period (November, 2014-March, 2015), the levels of indoor settled dust were fairly uniform (4.475 - $\left.6.533 \mathrm{~g} / \mathrm{m}^{2}\right)$ throughout all the sampling sites as depicted in Table 2. Dust loading within the indoor environment of the University of Agriculture Makurdi during the period of this investigation followed the order of $\mathrm{VM}<\mathrm{FT}<\mathrm{SC}<\mathrm{AE}<\mathrm{AS}<\mathrm{AG}<\mathrm{EN}$ with an overall loading of $5.288 \mathrm{~g} / \mathrm{m}^{2}$ $\left(1.058 \mathrm{~g} / \mathrm{m}^{2} /\right.$ month). The level of dust loading may be due to various human activities such as construction works, Agricultural activities as well as heavy traffic within and outside the University environment. This may also originate from natural source such as soil dust [17]. Highest level of indoor settled dust (value of $6.533 \mathrm{~g} / \mathrm{m}^{2}$ ) was recorded for the College of Engineering (EN), while the College of veterinary medicine (VM) recorded the least amount of indoor settled dust with a value of $4.475 \mathrm{~g} / \mathrm{m}^{2}$. Dust loading was expectedly higher along high traffic, untarred roads, construction sites as well as old buildings which were the cases for the College of Engineering (EN) and some others. Indoor settled dust as reported by Fairus et al. [6] may also be influenced by building type (Double storey, single storey, and corner lot), ventilation condition as well as land use background.

Smaller particles of dust find their way into the lungs and depending on the size get deposited therein causing respiratory problems [18]. Heavy metals of anthropogenic origin can be ingested directly by occupants through unintentional hand to mouth contact or by inhalation of dust [19]. However, the overall mean of dust loading $\left(1.058 \mathrm{~g} / \mathrm{m}^{2} / \mathrm{month}\right)$ as reported in this study was found to be above $0.0079 \mathrm{~g} / \mathrm{m}^{2} / \mathrm{month}$ reported for the Eastern Mazowwieckie Province by Krolak [20] but below the South African National Standard (SANS) threshold limit of $18 \mathrm{~g} / \mathrm{m}^{2} /$ month in Narayan et al. [21].

\subsection{Heavy Metal Concentration}

The results of heavy metal concentration for each of the seven sample locations including the control sites from November, 2014-March, 2015 are presented with graphical plots in Figures 2-5. Pearson Correlation matrix showing the relationship (at 0.05 level of significance) between the metals under study is depicted in Table 3 , while Table 4 shows Comparison of heavy metal concentration $(\mathrm{mg} / \mathrm{kg})$ in dust samples found in the present study with those reported in literature.

Copper: $\mathrm{Cu}$ is an essential element in our diet but at elevated doses, it causes anaemia, liver and kidney damages, stomach and intestinal irritation. Excessive intake of $\mathrm{Cu}$ may also result in death with symptoms such as hypertension, coma and jaundice [22]. Within the period of this research, the concentration of $\mathrm{Cu}$ in the study 
Table 2. Indoor dust loading within the University of Agriculture Makurdi.

\begin{tabular}{cccc}
\hline Sample Location & Total Dust $(\mathbf{g})$ & Total Area $\left(\mathbf{m}^{2}\right)$ & Dust Loading $\left(\mathbf{g} / \mathbf{m}^{2}\right)$ \\
SC & $0.621 \pm 0.001$ & 0.120 & 5.175 \\
VM & $0.537 \pm 0.033$ & 0.120 & 4.475 \\
FT & $0.569 \pm 0.024$ & 0.120 & 4.742 \\
EN & $0.784 \pm 0.033$ & 0.120 & 5.533 \\
AG & $0.682 \pm 0.008$ & 0.120 & 5.683 \\
AE & $0.623 \pm 0.061$ & 0.120 & 5.192 \\
AS & $0.626 \pm 0.060$ & 0.120 & 5.217 \\
\hline
\end{tabular}

$\mathrm{SD}=$ Standard Deviation

Table 3. Correlation matrix for heavy metal concentrations.

\begin{tabular}{ccccc}
\hline Element & $\mathrm{Cu}$ & $\mathrm{Fe}$ & $\mathrm{Mn}$ & $\mathrm{Zn}$ \\
$\mathrm{Cu}$ & 1 & $0.818^{*}$ & $0.806^{*}$ & 0.670 \\
$\mathrm{Fe}$ & $0.818^{*}$ & 1 & 0.630 & 0.712 \\
$\mathrm{Mn}$ & $0.806^{*}$ & 0.630 & 1 & 0.352 \\
$\mathrm{Zn}$ & 0.670 & 0.712 & 0.352 & 1 \\
\hline
\end{tabular}

${ }^{*}$ Correlation is significant at the 0.05 level (2-tailed).

Table 4. Heavy metal concentrations (mg/kg) in comparison with reported studies.

\begin{tabular}{|c|c|c|c|c|c|}
\hline \multirow{2}{*}{ Author } & \multicolumn{4}{|c|}{ Heavy Metal Concentration } & \multirow{2}{*}{ Study Area } \\
\hline & $\mathrm{Cu}$ & $\mathrm{Fe}$ & Mn & Zn & \\
\hline Current Study & $0.2372-0.7152$ & $293.6-884.9$ & $4.265-68.55$ & $4.239-42.53$ & $\begin{array}{c}\text { University of Agriculture } \\
\text { Makurdi }\end{array}$ \\
\hline Yap et al. [27] & $87.50-442.0$ & $3445-3852$ & NA & $439.0-880.0$ & $\begin{array}{c}\text { Selangor School, } \\
\text { Malaysia }\end{array}$ \\
\hline Chattopadhyay et al., [28] & 147.0 & NA & NA & 657.0 & Sydney, Australia \\
\hline Mgbamena and Onwukeme [10] & $12.75-34.75$ & $2701-2798$ & $87.50-124.5$ & $160.0-161.0$ & Aba, Nigeria \\
\hline Ibrahim et al., [26] & $0.860-3.120$ & $1111-2436$ & $10.03-24.99$ & NA & Amber Province, Iraq \\
\hline Adekola and Dosumu [2] & 0.510 & 40.60 & NA & NA & $\begin{array}{l}\text { University of Ilorin, } \\
\text { Nigeria }\end{array}$ \\
\hline
\end{tabular}

NA = Not Applicable, ND = Not Detected

area ranges from $0.2372-0.7152 \mathrm{mg} / \mathrm{kg}$. The highest concentration was recorded at the College of Engineering (EN) while the lowest concentration of $\mathrm{Cu}$ was recorded at the College of Animal Science (AS) as depicted in Figure 2. The presence of $\mathrm{Cu}$ in indoor settled dust are believed to be from anthropogenic sources such as automobile emissions and street dust, car components, tyre abrasion, brushing, bearing and brake dust [23] [24]. The occurrence of $\mathrm{Cu}$ in the study area may also be due to the weathering of a unique form of a local geological material due to wind erosion and construction work. 


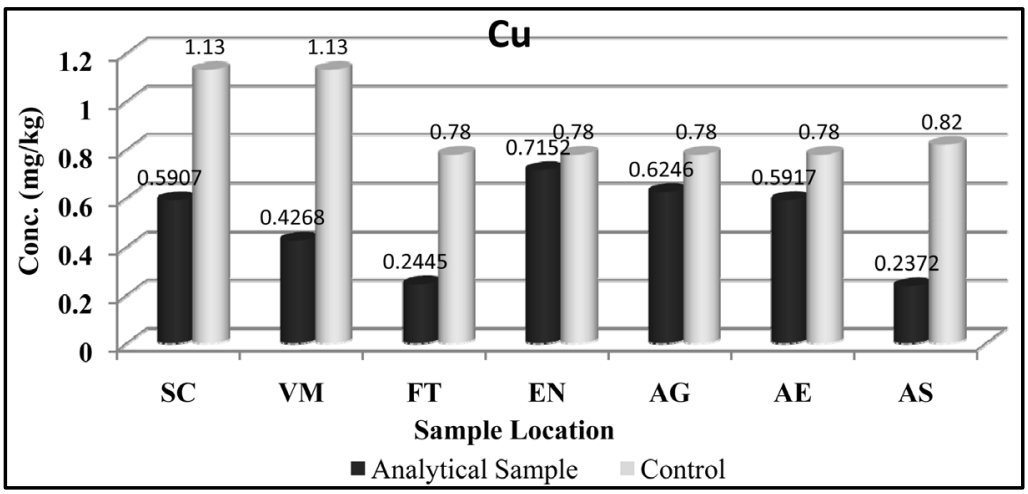

Figure 2. Concentration of $\mathrm{Cu}$ in indoor settled harmattan dust.

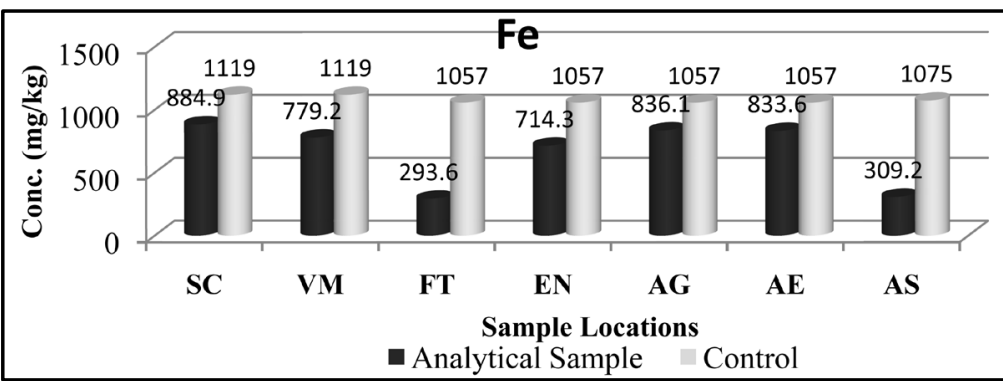

Figure 3. Concentration of Fe in indoor settled harmattan dust.

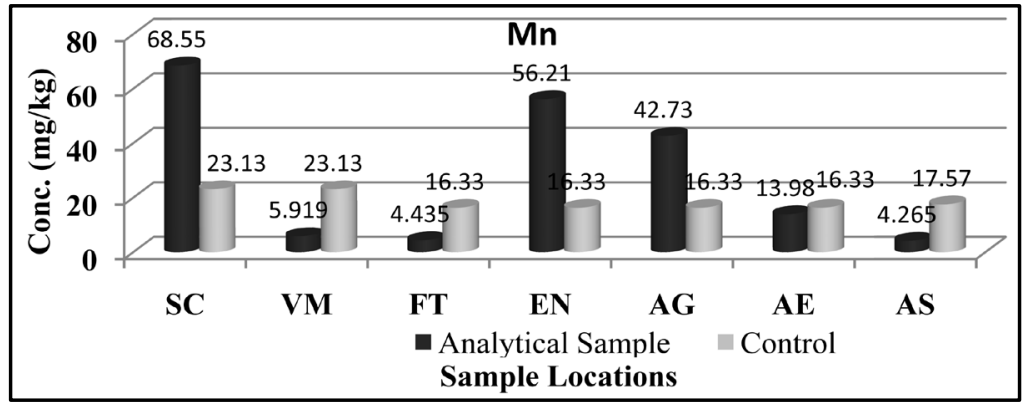

Figure 4. Concentration of Mn in indoor settled harmattan dust.

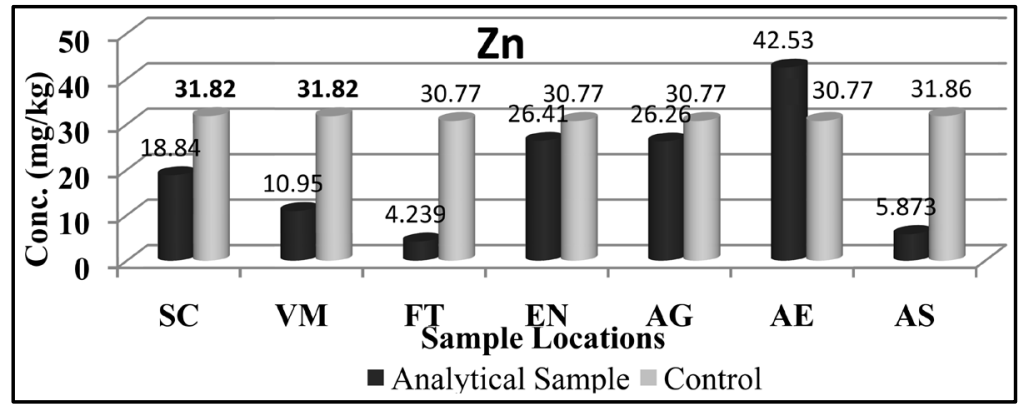

Figure 5. Concentration of $\mathrm{Zn}$ in indoor settled harmattan dust.

Iron: Fe is an abundant element in the earth crust [23]. The element has been produced by alteraction (friction) and transported via wind and can be associated with soil or street dust. The concentration of Fe determined in this study within the period of assessment is fairly high throughout all the sampling sites. The concentration of Fe ranges from 293.6 - 884.9, with the highest value recorded at the College of Science (SC) while the lowest 
value was recorded at the College of Food Technology (FT) as shown in Figure 3. The high concentration of Fe in the study area may be traceable to its abundance in the earth crust. This further buttresses the fact that soil and street dust play an important role in the concentration build up of heavy metals in indoor settled dust [23].

Manganese: $\mathrm{Mn}$ is an essential nutrient element for both plants and animals. However, very high concentration of Mn could be dangerous. The concentration of Mn determined in all the sites within the period of assessment ranges from $4.265-68.55 \mathrm{mg} / \mathrm{kg}$, with the highest value recorded at the College of Sciences (SC) while the lowest concentration of Mn was recorded at the College of Animal Science (AS) as depicted in Figure 4. The high level of Mn at the College of Science (SC) and other sites may be as a result of laboratory reagent emissions resulting from the improper disposal of chemical wastes containing Mn and its compounds. The presence of $\mathrm{Mn}$ in indoor settled dust may also be traceable to anthropogenic activities around the sites such as the combustion of Mn rich fuel enhancers [25].

Zinc: $\mathrm{Zn}$ is one of the most common elements in the earth crust. It is found in air, soil and water. Zn attaches to dust particles in air which settles as $\mathrm{Zn}$ dust particles. $\mathrm{Zn}$ is an essential element in our diet, insufficient amount of it can cause health problems and too much of it can be harmful. According to Mafuyai et al. [25], the presence of $\mathrm{Zn}$ in the atmosphere could be attributed to wind-blown soil, road dust as well as the weathering of a unique form of local geological materials due to wind erosion, construction work and heavy traffic conditions. The concentration of $\mathrm{Zn}$ in indoor settled dust in all the sampling stations within the period of this research was in the range of $4.239-42.53 \mathrm{mg} / \mathrm{kg}$ as shown in Figure 5. Zn concentration was highest at the College of Agricultural Economics (AE) while the lowest value was recorded at the College of Veterinary Medicine (VM). The proximity of College buildings to roads with high traffic density may have contributed to the presence of $\mathrm{Zn}$ in indoor settled dust. Similarly, the Zn content may have originated from the wear and tear of vulcanized vehicle tyres, and corrosion of galvanized automobile parts [23].

All the metals investigated ( $\mathrm{Cu}, \mathrm{Fe}, \mathrm{Mn}$ and $\mathrm{Zn}$ ), were found to be below the maximum permissible limits of heavy metals in dust as reported by Ibrahim et al. [26], Mgbemena and Onwukeme [10]. Results of the control samples as depicted in Figures 2-5 have heavy metal concentrations higher than those obtained from the indoor assessment, (except the Colleges of Agronomy (AG), Agricultural Economics (AE) and Sciences (SC) which Showed higher levels of $\mathrm{Zn}$ and Mn indoors than outdoor). Ibrahim et al. [26] also reported higher concentrations of heavy metals in outdoor dust than those obtained for indoor settled dust in Ambar province, Iraq. However, the higher concentrations of $\mathrm{Mn}$ and $\mathrm{Zn}$ indoors than outdoor in some Colleges may be traceable to a long history of contamination in such offices attached to laboratories that was built in 1980s.

\subsection{Statistical Analysis}

The Pearson correlation matrix for heavy metal concentration in studied samples as shown in Table 3 indicates positive correlation between all the possible pairs of heavy metals at $95 \%$ confidence level. High positive correlation was found between $\mathrm{Cu}-\mathrm{Fe}(\mathrm{r}=0.818)$ and $\mathrm{Cu}-\mathrm{Mn}(\mathrm{r}=0.806)$. This result suggests that the metals originate from similar sources which may be from wear and tear of automobile parts, street dust, soil dust, construction works and other related activities

\subsection{Comparative Studies}

Table 4 shows the comparison between the concentrations of heavy metals in indoor settled harmattan dust from the University of Agriculture Makurdi with those reported in literature. The levels of heavy metal pollutants from the indoor environment of the University of Agriculture Makurdi during the period of this assessment were lower than other reported values. This may be due to several factors such as differences in levels of industrial activities, traffic density, population density and natural concentrations of those particular metals in the earth crust.

The maximum values for all the metals reported in the present study are lower when compared with those reported by Yap et al. [27] for Selangor schools in Malaysia. Similarly, the concentrations of heavy metals in settled dust reported for Sidney in Australia by Chattopadhyay [28] were found to be higher than the maximum values reported for the same metals in the present study. The concentrations of all the heavy metals reported by Mgbemena and Onwukeme [10] for Aba, Nigeria were also found to be above the reported values for the current study. However, Adekola and Dosumu [2] reported lower levels of $\mathrm{Cu}$ and $\mathrm{Fe}$ in indoor settled dust from the University of Ilorin, Nigeria. 


\subsection{Conclusion}

The masses of indoor settled harmattan dust within the University of Agriculture Makurdi were higher along high traffic, untarred roads and construction sites as well as in older buildings than others during the period of this study, indoor dust loading was in order of $\mathrm{VM}<\mathrm{FT}<\mathrm{SC}<\mathrm{AE}<\mathrm{AS}<\mathrm{AG}<\mathrm{EN}$. However, within the period of this research, dust loading in all the College buildings was below SANS (South African National Standard) threshold limit of $18 \mathrm{~g} / \mathrm{m}^{2} /$ month Similarly, the results of this study show that $\mathrm{Cu}, \mathrm{Fe}$, Mn and Zn were detected in indoor settled dust samples investigated within the University of Agriculture Makurdi in order of Cu < $\mathrm{Mn}<\mathrm{Zn}<\mathrm{Fe}$. The concentrations of these metals were compared with reported values from some popular cities and institutions around the world. The results indicated that the metals were of lower concentrations than reported literature values. This indicates that heavy metals in dust are higher in more industrialized and densely populated cities than otherwise. Similar case may also exist in areas where buildings are located close to roads and construction sites. All the investigated metals in the present study showed concentrations within acceptable limits. However, indoor settled dust can be drastically reduced by frequent wet mopping and vacuuming, also by minimizing the use of windows during the harmattan season.

\section{References}

[1] Minka, N.S. and Ayo, J.O. (2013) Influence of Cold-Dry Harmattan Season on Colonic Temperature and the Development of Pulmonary Hypertension in Broiler Chickens, and the Modulating Effect of Ascorbic Acid. Dove Press Journal (Open Access Animal Physiology), 5, 115-121.

[2] Adekola, F.A. and Dosumu, O.O. (2001) Heavy Metal Determination in Household Dusts from Ilorin City, Nigeria. Journal of Nigerian Society for Experimental Biology, 1, 217-221.

[3] Dimari, G.A., Hati, S. S., Waziri, M. and Maitera, O.N. (2008) Pollution Synergy from Particulate Matter Sources: The Harmattan Fugitive Dust and combustion Emission in Maiduguri Metropolis Nigeria. European Journal of Scientific Research, 23, 465-471.

[4] USEPA (2012) Air Quality Criteria for Particulate Matter. Vol. 1 - 3, Office of Research and Development, Washington DC (EPA Report No. EPA/001a-c).

[5] Ediagbonya, T.F., Ukpebor, E.E. and Okieimen, F.E. (2013) Heavy Metal in Inhalable and Respirable Particles in Urban Atmosphere. Journal of Environmental Skeptics and Critics, 2, 108-117.

[6] Rashad, M. and Shalaby, E.A. (2007) Dispersal and Deposition of Heavy Metals Around two Municipal Solid Waste (MSW) Dump Sites, Alexandra, Egypt. American European Journal of Agricultural and Environmental Science, 2, 204-212.

[7] Fairus, M.D., Rabiatul, A.N., Siti, M.S., Zitty, S.I. and Nur, A.O. (2012) Heavy Metals Composition of Indoor Dust in Nursery School Building. Proceedia-Social and Behavioural Sciences, 38, 169-175. http://dx.doi.org/10.1016/j.sbspro.2012.03.337

[8] Nor Aimi A.W., Fairus, M.D., Norain, I. and Siti, M.S. (2012) Heavy Metal Concentration of Settled Surface Dust in Residential Building. Malaysian Journal of Analytical Sciences, 16, 18-23.

[9] Meena, M., Singh, B., Chandrawat, U. and Rani, A. (2014) Seasonal Variations and Sources of Heavy Metals in Free Fall Dust in an Industrial City of Western India. Iranica Journal of Energy \& Environment, 5, 160-166. http://dx.doi.org/10.5829/idosi.ijee.2014.05.02.07

[10] Mgbemena, M.N and Onwukeme, V.I. (2012) Heavy Metal in Dust Samples from Aba, Abia State, Nigeria, Using Car Wind Screen as Inert Passive Collector. Journal of Applied Chemistry, 3, 53-56. http://dx.doi.org/10.9790/5736-0315356

[11] Gbadebo, A.M. and Bankole, O.D. (2007) Analysis of Potentially Toxic Metals in Airborne Cement Dust around Sagamu, Southwest, Nigeria. Journal of Applied Science, 7, 35-40. http://dx.doi.org/10.3923/jas.2007.35.40

[12] American Society for Testing and Materials (2002) Practice for Collection of Settled Dust Samples Using Wipe Sampling Methods for Subsequent Lead Determination and Platinum Group Metals in Thohoyandou, South Africa. ASTM E1728. Water SA, 31, 581-586.

[13] McDonald, L., Rasmussen, T., Pat, E., Chénier, M. and Levesque, C. (2010) Wipe Sampling Methodologies to Assess Exposures to Lead and Cadmium in Urban Canadian Homes. Proceedings of the Annual International Conference on Soils, Sediments, Water and Energy, 15, 52-66.

[14] National Institute for Occupational Safety and Health (NIOSH) (1994) Manual of Analytical Methods. Fourth Edition, Lead in Surface Wipe Samples: Method 9100.

[15] Brookhaven National Laboratory (Industrial Hygiene Division) (2014) Surface Wipe Sampling Procedure (IH75190). 
[16] Kulshrestha, A., Massey, D., Masih, J. and Ajay, T. (2014) Source Characterization of Trace Elements in Indoor Environments at Urban, Rural and Roadside Sites in a Semi Arid Region of India. Journal of Aerosol and Air Quality Research, 14, 1738-1751.

[17] Elbagir, S.G. (2011) Characterization and Source Identification of Selected Pollutants in House Dust. Unpublished M.Sc Thesis, Queensland University of Technology, Brisbane.

[18] Masters, G.M. (1998) Introduction to Environmental Engineering and Science. 2nd Edition, Prentice Hall Ltd., London, 327-451.

[19] White, P.D., Van, P., Leevween, H. and Davis, B.D. (1998) The Conceptual Structure the Integrated Exposure Uptake Biokinetic Model For Lead in Children. Journal of Environmental Health Perspective, 106, 1513-1530. http://dx.doi.org/10.1289/ehp.98106s61513

[20] Krolak, E. (2000) Heavy Metals in Falling Dust in Eastern Mazowieckie Province. Polish Journal of Environmental Studies, 9, 517-522.

[21] Narayan, D., Agrawal, M., Pandi, J. and Singh, J. (1994) Change in Vegetation Characteristics Downwind of an Aluminium Factory in India. Annals of Botany, 73, 557-565. http://dx.doi.org/10.1006/anbo.1994.1069

[22] Thornton, I., Watt, J.M., Davies, D.J.A., Hunt, A., Cotter-Howells, J. and Johnson, D.L. (1994) Lead Contamination of UK Dusts and Soils and Implications for Childhood Exposure: An Overview of the Work of the Environmental Geochemistry Research Group, Imperial College, London, England 1981-1992. Environmental Geochemistry and Health, 16, 113-122. http://dx.doi.org/10.1007/BF01747907

[23] Al-Khashman, A.O. (2004) Heavy Metal Distribution in Dust, Street Dust and Soils from the work Place in Korak Industrial Estate, Jordan. Journal of Atmospheric Environment, 38, 6803-6812. http://dx.doi.org/10.1016/j.atmosenv.2004.09.011

[24] Al-Rahji, M.A. and Seaward, M.R.D. (1996) Metal Levels in Indoor and Outdoor Dust in Riyadh, Saudi Arabia. Journal of Environmental International, 22, 315-324. http://dx.doi.org/10.1016/0160-4120(96)00017-7

[25] Mafuyai, G.M., Eneji, I.S. and Sha'Ato, R. (2014) Concentration of Heavy Metals in Respirable Dust in Jos Metropolitan Area, Nigeria. Open Journal of Air Pollution, 3, 10-19. http://dx.doi.org/10.4236/ojap.2014.31002

[26] Ibrahim, Q.A., Anmar, D.K. and Azimi, T.H. (2013) Measuring the Concentrations of Some Heavy Elements Indoor and Outdoor During Dust Storms in Anbar Province, Iraq. International Journal of Emerging Technology and Advanced Engineering, 2, 578-582.

[27] Yap, C.K., Krishnan, T. and Chew, W. (2011) Heavy Metals Concentration in Ceiling Fan Dust Sampled at Schools around Serdang Area, Selangor. Sains Malaysiana, 40, 569-575.

[28] Chattopadhyay, G., Lin, K.C.P. and Feitz, A.J. (2003) Indoor Dust Metal Levels in the Sidney Metropolitan Area. Journal of Environmental Research, 93, 301-307. http://dx.doi.org/10.1016/S0013-9351(03)00058-6 